\title{
Doctrine of Cosmeceutics in Ayurveda \\ Vrinda*
}

Department of Rasashastra and Bhaishajya Kalpana, India

*Corresponding Author: Vrinda, Department of Rasashastra and Bhaishajya Kalpana, India, Tel: +919035996258; E-mail: vrindabhat_89@yahoo.co.in Received date: July 03, 2018; Accepted date: August 02, 2018; Published date: August 09, 2018

Copyright: (c) 2018 Vrinda. This is an open-access article distributed under the terms of the Creative Commons Attribution License, which permits unrestricted use, distribution, and reproduction in any medium, provided the original author and source are credited.

\begin{abstract}
Concept of Aesthetics can be traced since days of yore. Beauty is an external appearance representing one's inner self. Ayurveda assesses beauty by Prakruti (Constitution), Saara Structural predominance), Samhanana (Compactness), Twak (Skin), Pramana (Measurement), Dirghayu lakshana (Signs of longevity). One of the criteria to determine Dirghayu Lakshana is soft, black coloured. Firm, oily hair which is attached to a single hair root. In Ayurveda, Kesha (Hair) has been described in different prospects. They provide implication of Prakruti (Copper/ Brown coloured hair-Pitta Prakruti) and Saara (Beautiful, lustrous hair Medo saara) of an individual, appraises the Swastha (Healthy) and Atura (III-health) condition of a person (Increased hair fall indicates decreased quality of Asthi). They are also a tool for treatment purpose (Fumigation of hair for the treatment of Arsha-Hemarrhoids). Aforesaid is the emphasis laid on hair. Treatment and maintenance of black, lustrous and a healthy scalp hair as well as removal of unwanted bodily hair have also been elucidated.

According to Acharya Charaka, a Twak saara purusha comprises of Snigdha (Lustrous), Shlakshna (Silky in touch), Komala (Soft), Prasanna (Attractive), Sookshma (Thin) and Prabha yukta (Shiny) skin. Various treatises have portrayed cosmetology through inner mitigation of derangement. Comprehensively it includes Ama pachana (Digestion of unwanted toxins), Mala shudhikarana (Cleansing the intestine), Rakta prasadana (Improving circulation), Rakta shodhana (Purification of blood) etc. Both Hydrophilic (Water) and lipophilic Medias (Milk, ghee etc.) are mentioned to be used as media for external application depending on the properties of the drugs and pathology of disease. Preventive measures to circumvent diseases, prolong ageing and stay young and beautiful are possible to be achieved by Rasayana chikitsa (Rejuvenation therapy). Hence Ayurveda gives a holistic approach to cosmeceutics.
\end{abstract}

Keywords: Prakruti; Saara; Samhanana; Twak; Pramana; Dirghjayu lakshana; Twak saara purusha; Aama pachana; Mala shudhikarana; Rakta prasadana; Rasayana chikitsa

\section{Introduction}

Healthy skin and hair is an epitome of inner wellness. Wellness is not just the absence of illness; it is a dynamic process of change and growth [1-4]. In Sanskrit, the word 'body' is termed as "Shareera" which means that which is subjected to deterioration [5]. In order to protect this body from disease and ageing and enhance the beauty of the body, various measures were incorporated by human beings since time immemorial. An attempt has been made in this article to give a comprehensive approach to augment the beauty in terms of skin and hair.

We find references of usage of cosmetics since Vedic period. Rigveda has mentioned different types of Lepas (external application) of various herbs. Garuda purana has cited various beautifying yogas. Mahabharata, in Anushasana Parva has quoted that one must perform Chandrayana Vrata in Mrigashira Masa (November-December) to acquire beauty and popularity. Narration of the bride "Draupadi" during the time of Swayamvara and her role as Sairandhri (Aesthetician) is an example of cosmetic secure which existed in that period [6].

In treatises of Ayurveda, insight of cosmetology begins from the fundamentals of anatomy and physiological functions of hair and skin. Acharya Sushruta has mentioned seven layers of skin, their dimensions and the manifestations of different skin disorders from different layers along with their treatment. The natural Varna (complexion) of skin mainly depends on the combination of Pancha mahabhoota (Five elements) at the time of conception. Tejo mahabhoota (Fire element) is the fundamental entity of the colour of skin. When it combines with Aap mahabhoota (Water element), it gives rise to Goura varna (Fair complexion). When Tejas and Prithvi mahabhoota (Earth element) merge, it results in Krishna varna (Dark complexion). Prithvi in association with Aakasha Mahabhoota (Space element) forms Krishna shyama varna (Blue-black complexion). Aap and Aakasha mahabhoota merge to form Goura shyama Varna (whitish-blue complexion) [7]. Other than Mahabhoota, internal factors like Rakta dhatu (Blood) and Bhrajaka pitta (Type of Pitta) seated in the skin are responsible for glow of one's natural complexion.

Cosmeceutics with reference to skin and hair in Ayurveda can be divided into three entities.

They are as follows:

Treatment of skin and hair disorders.

Beautification of skin and hair.

Prevention of signs of ageing and maintenance of a healthy skin and hair. 


\section{Treatment of skin and hair disorders}

Skin and hair disorders are the manifestation of impairment of body system. Both internal and external measures are adopted for their treatment.

Medicines: Medicines which eliminate Aama (undigested food or toxins) from the body or that which acts on Rakta (Blood) and Pitta; categorised under Kushtahara (Pacifies skin disorders), Twachaagnivardhaka (Stimulates enzymes related to skin), Sandhaneeya (Improves collagen formation), Vrana ropana (Wound healing); Savarnakarana (restoring normal colour) normalises the derangement and thus pacifies the skin disorders. Similarly Keshya (Conducive to hair) and Kesha Krishneekarana (Blackening of hair) drugs have been mentioned in Ayurvedic treatises.

The non-invasive techniques: The non-invasive technique of Panchakarma therapies like Virechana, Basti, Nasya and Jaloukavacharana are highly beneficial in their treatment. Virechana eliminates the vitiated Pitta and other toxins from the body. As per Acharya Charaka, it also benefits the body by enhancing complexion [8].

During the procedure of Basti, the medicated enema is believed to show its effects on the entire body. According to Kashyapa, Yapana Basti has Rasayana property and it nourishes the body up to hair and nails [9].

Nose is the doorway to Shiras (Head). This therapy is highly beneficial for both skin and hair. Rich vascular plexus in the nasal tissue makes it a site for rapid absorption. The lateral nasal veins are connected to the angular veins which are the uppermost segment of the facial vein which helps to show local effect. Nasya karma also shows systemic effect especially of neurological, endocrinal and circulatory functions [10]. Hence skin and hair disorders originated from the above system subside.

Jaloukavacharana or Hirudotherapy is believed to eliminate the vitiated blood from the body and thus used in all skin disorders. Leech saliva contains several bio-active substances like prostaglandins, vasodilators, anesthetics and proteins like calin, apyrasehyaluronidase, egline, destabliase, piyavit and kollaginase [11]. These enzymes released into the body might provide anti-inflammatory, wound healing and other dermatological benefits. Nowadays leech therapy is adopted to treat swelling after plastic surgery and graft operations and is considered to be anti-phlogistic. They are also used in post-operative care of re-implanted finger, skin grafting and breast reconstruction.

External therapies: External therapies for hair include Shiro Abhyanga (Head massage), Shiro lepa (application of paste to head) and Shiro pichchu (Placing of medicated drugs over the head). External therapies for skin include Mukha abhyanga (Facial massage), Swedana (Fomentation), Udwartana (Scrub), and Mukha lepa (Face packs).

Abhyanga: Abhyanga is the widely practiced measure to treat various disorders related to skin and hair. Massage in specific direction improves blood circulation, facilitates removal of toxins from the tissues and recuperates the body tissues [12]. According to Acharya Charaka, it prevents wear and tear viz. it prevents degenerative changes of the body [8]. Few formulations used in the treatment of skin disorders are Brihat Marichyadi taila, Kumkumadi taila, Manjishtadi taila, Eladi taila, Kanaka taila.
Abhyanga to scalp not only increases blood flow but also directly stimulates the dermal papilla cells by mechanical force. The stretchy forces can change the gene expression related to hair cycle. Mechanical stress also influence signalling pathway and accelerate the anagen phase of hair cycle [13]. Few formulations which promote hair growth are Nilibhringadi taila, Bhringamalakadi taila, Malatyadi taila, Kayyanyadi taila, Chandanadi taila, Yashtimadhu taila.

Lepa kalpana on hair: The drugs to treat Palitya (Canities) are generally mixed with suitable media and applied as a dye on hair and washed after speculated time or are used in the preparation of oils for Abhyanaga. The commonly used drugs are Triphala, Neeli, Madayantaka, Akshota etc. Hareetaki (Terminalia chebula), Vibhitaki (Terminalia bellirica) present in Triphala contains Gallic acid and Tannic acid. Gallic acid forms a complex with iron ions in hair to achieve a good chromaticity and fastness of the dyed hair. Tannic acid is a type of polyphenol useful as yellow dye for hair. Emblicans and Ellagic acid in Amalaki (Phyllanthus emblica) herb are a type of polyphenol which are traditionally used as dyes. Bhringaraja (Eclipta alba) contains yellow crystalline flavones. Apigenin and Luteolin present in it give dyeing property. Luteolin is present in Neeli (Indigofera tinctoria) herb. Indigo dye with a distinctive blue colour can be extracted from the leaves of Neeli. Lawsone, also known as Hennotannic acid, is a red orange dye present in the leaves of Madayantha (Lawsonia inermis) herb used for hair dyeing. Akshota (Juglans regia) herb contains Regianin, an organic compound having the tendency to create dark brown stains to hair. Haematoxylin is a black colouring compound present in the heart wood of Patanga (Caesalpinia sappan) herb used in dyeing hair [14].

Lepa kalpana on skin: As per Acharya Sharangadhara, there are three kinds of Lepa depending on their functions-Doshagna lepa (which mitigates Vata, Pitta, Kapha), Vishagna lepa (which eliminates the bio-toxins) and Varnya lepa (which enhances complexion) [15]. Acharya Sushruta has classified lepaas Pralepa, Pradeha and Alepa. He has instructed the thickness of application of Lepa to be equivalent to moist buffalo's skin which is approximately $4-5 \mathrm{~mm}$ [7]. Hence to apply a thin Lepa, it must be less than $4 \mathrm{~mm}$ and for a thick Lepa, it must be more than $5 \mathrm{~mm}$. Whereas Acharya Charaka clarifies that when a rubeficient action of a drug is expected, it should be applied uniformly thick over skin. However when soothing and softening action is to be elicited, the drug should be applied uniformly thin over the skin. This statement interprets the mode of application of a drug as per the requirement and not the properties of the drugs [16].

The physico-chemical properties of a drug mainly affect the drug's trans-dermal delivery and topical bio-availability. The molecules of the formulation after penetrating through the stratum corneum and into viable epidermis and dermis produce its characteristic pharmacological response through receptors. Besides this route, the drug molecules may also penetrate through the hair follicles and sebaceous glands or through sweat ducts also [17]. Few formulations of Mukha Lepa quoted for different skin conditions are depicted below in Table 1 [18].

\begin{tabular}{|l|l|l|}
\hline Formulation & Media & Condition \\
\hline $\begin{array}{l}\text { Lodhra twak (Bark of Symplocos } \\
\text { racemosa), Dhanyaka beeja } \\
\text { (Seeds of Coriandrum sativum), } \\
\text { Vacha (Acorus calamus) }\end{array}$ & Water & $\begin{array}{l}\text { Youvana pidaka } \\
\text { (Acne) }\end{array}$ \\
\hline
\end{tabular}


Page 3 of 5

\begin{tabular}{|c|c|c|}
\hline $\begin{array}{l}\text { Arjuna twak (Bark of } \\
\begin{array}{l}\text { arjuna), } \\
\text { cordifolia) }\end{array}\end{array}$ & Honey & Vyanga (Melasma) \\
\hline $\begin{array}{l}\text { Rakta chandana (Pterocarpus } \\
\text { santalinus), Manjishta (Rubia } \\
\text { cordifolia), } \\
\text { Kushta (Saussurea lappa), } \\
\text { Lodhra (Symplocos racemosa), } \\
\text { Priyangu flower (Callicarpa } \\
\text { macrophylla), Vatankura (Ficus } \\
\text { benghalensis) and Masoora } \\
\text { (Lens culinaris) }\end{array}$ & Goat's or Cow's milk & Vyanga (Melasma) \\
\hline $\begin{array}{l}\text { Matulunga } \\
\text { Manahshila } \\
\text { sulphide) }\end{array}$ & $\begin{array}{l}\text { Ghee and juice of } \\
\text { cowdung }\end{array}$ & $\begin{array}{l}\text { Tilakalaka } \\
\text { (Blackheads) }\end{array}$ \\
\hline Fried Masoora (Lens culinaris) & Milk & $\begin{array}{l}\text { Varnyakaraka (Skin } \\
\text { whitening) }\end{array}$ \\
\hline $\begin{array}{lr}\text { Yava (Hordeum } & \begin{array}{l}\text { vulgare), } \\
\text { Yashtimadhu }\end{array} \\
\text { glabra), Lodhryrrhiza } & \text { (Symplocos } \\
\text { racemosa) } & \end{array}$ & Water & $\begin{array}{l}\text { Varnyakaraka (Skin } \\
\text { whitening) }\end{array}$ \\
\hline
\end{tabular}

Table 1: Few formulations of Mukha Lepa

\section{Beautification}

Ayurveda mentions various drugs to enhance beauty under the category of Varnya, Kantivardhaka, etc. for skin and Keshya, Lomashtana, etc. for hair.

Skin beautifiers: Research works on few of the Varnya drugs have shown the presence of Tyrosine inhibition activity. Tyrosine enzyme present in Melanocytes form melanin by oxidation through free radical coupling pathway. Melanin is responsible for dark colouration of skin. Anti-oxidant property exhibited by few herbs also has a role to play on pigmentation. They quench the free radicals and help in reducing the synthesis of melanin thereby contributing to skin de-pigmentation. The Table 2 below depicts few herbs along with their dermatological action [19].

\begin{tabular}{|l|l|l|}
\hline Drug & Phytochemicals & Action \\
\hline $\begin{array}{l}\text { Shwetha Chandana } \\
\text { (Santalum album) }\end{array}$ & $\begin{array}{l}\text { Sandalwood oil is rich in } \\
\text { sesquiterpenoid alcohols } \\
(80 \%-90 \%) \\
\text { Sandalwood oil mainly } \\
\text { contains alpha-santalol }\end{array}$ & Tyrosine inhibitor \\
\hline $\begin{array}{l}\text { Yashtimadhu } \\
\text { (Glycyrrhiza glabra) }\end{array}$ & Glycyrrhizetic acid & $\begin{array}{l}>7 \% \text { Tyrosine inhibition } \\
\text { Controls } \\
\text { secretion }\end{array}$ \\
\hline $\begin{array}{l}\text { Manjishta } \\
\text { (Rubia cordifolia) }\end{array}$ & $\begin{array}{l}\text { Glucosides known as anin } \\
\text { Purpurine. } \\
\text { Also resins, lime salts } \\
\text { and coloring agents }\end{array}$ & $\begin{array}{l}14.80 \% \\
\text { inhibition }\end{array}$ \\
\hline $\begin{array}{l}\text { Nagakesara } \\
\text { (Mesua ferrea) }\end{array}$ & $\begin{array}{l}\text { Phenyl coumarins, } \\
\text { xanthones, triterpenoids, } \\
\text { flavonoids }\end{array}$ & $\begin{array}{l}\text { Tyrosine inhibitor } \\
\text { Protection from UV rays }\end{array}$ \\
\hline $\begin{array}{l}\text { Padmaka } \\
\text { cerasoides) }\end{array}$ & $\begin{array}{l}\text { Flavanone, Glycoside } \\
\text { pudduvil-B }\end{array}$ & $\begin{array}{l}\text { Tyrosine inhibitor } \\
\text { Anti-melanogin activity }\end{array}$ \\
\hline
\end{tabular}

\begin{tabular}{|c|c|c|}
\hline $\begin{array}{l}\text { Ushira } \\
\text { (Vetiveria zizanioides) }\end{array}$ & $\begin{array}{l}\text { Tannins, Flavanoids, } \\
\text { Triterpenoids }\end{array}$ & $\begin{array}{l}\text { Tyrosine inactivation } \\
\text { Suppresses oxidative } \\
\text { stress in B16 melanoma } \\
\text { cells }\end{array}$ \\
\hline $\begin{array}{l}\text { Lodhra } \\
\text { (Symplocos racemosa) }\end{array}$ & Salireposides & $\begin{array}{l}\text { Acts against acne } \\
\text { producing bacteria } \\
6.60 \% \text { tyrosine inhibition }\end{array}$ \\
\hline $\begin{array}{l}\text { Kushta } \quad \text { (Saussurea } \\
\text { lappa) }\end{array}$ & $\begin{array}{l}\text { Odorous principle } \\
\text { composed of two liquid } \\
\text { resins, salt of Valeric } \\
\text { acid, Saussurine }\end{array}$ & $33.4 \%$ tyrosine inhibition \\
\hline $\begin{array}{l}\text { Twak (Cinnamomum } \\
\text { zeylanicum) }\end{array}$ & Essential oil & Tyrosine inhibitor \\
\hline $\begin{array}{l}\text { Kesar } \\
\text { (Crocus sativus) }\end{array}$ & $\begin{array}{l}>150 \quad \text { carotenoid } \\
\text { compounds } \\
\text { Riboflavin } \\
\text { Cyanides }\end{array}$ & $\begin{array}{l}\text { Tyrosine inhibitor } \\
\text { Anti-oxidant } \\
\text { Anti-pruritic } \\
\text { Complexion promotion }\end{array}$ \\
\hline $\begin{array}{l}\text { Haridra } \\
\text { (Curcuma longa) }\end{array}$ & Curcumin & $\begin{array}{ll}88.56 \% & \text { tyrosine } \\
\text { inhibition } & \end{array}$ \\
\hline $\begin{array}{l}\text { Daruharidra } \quad \text { (Berberis } \\
\text { aristata) }\end{array}$ & $\begin{array}{l}\text { Flavanoids, } \\
\text { Terpenes }\end{array}$ & $\begin{array}{l}\text { Ethanol extract- } 50 \% \text { anti- } \\
\text { oxidant potential } \\
\text { Methanolic } \\
\text { extract- } 20.80 \% \text { Tyrosine } \\
\text { inhibition activity }\end{array}$ \\
\hline $\begin{array}{l}\text { Nimba } \\
\text { (Azadirachta indica) }\end{array}$ & $\begin{array}{l}\text { Alakloids, glycosides, } \\
\text { saponins }\end{array}$ & $\begin{array}{l}\text { Bark-43.59\% tyrosine } \\
\text { inhibition } \\
\text { Leaf-10.10\% tyrosine } \\
\text { inhibition } \\
\text { Heartwood-anti-oxidant }\end{array}$ \\
\hline $\begin{array}{l}\text { Amalaki (Phyllanthus } \\
\text { emblica) }\end{array}$ & $\begin{array}{lr}\text { Tannins, } & \text { Saponins, } \\
\text { Glycosides, } & \text { Resins, } \\
\text { Sterols } & \end{array}$ & $\begin{array}{l}\text { Anti-oxidant } \\
\text { Stimulates UVB inhibited } \\
\text { cellular proliferation } \\
\text { Protects pro-collagen } \\
\text { against UVB-induced } \\
\text { depletion } \\
\text { Hyaluronidase inhibition }\end{array}$ \\
\hline $\begin{array}{l}\text { Haritaki } \quad \text { (Terminalia } \\
\text { chebula) }\end{array}$ & $\begin{array}{l}\text { Glycosides, flavanoids, } \\
\text { Tannins }\end{array}$ & $\begin{array}{l}\text { Inhibitory activity against } \\
\text { melanogenesis in B16 } \\
\text { melanoma cells } \\
\text { Isoterchebulin reduced } \\
\text { protein levels of } \\
\text { MITF, Tyrosine and its } \\
\text { related proteins }\end{array}$ \\
\hline $\begin{array}{l}\text { Shunti } \\
\text { officinale) }\end{array}$ & 6-gingerol & $\begin{array}{l}\text { Tyrosine inhibition } \\
\text { Decreased intracellular } \\
\text { reactive oxygen species } \\
\text { (ROS) level }\end{array}$ \\
\hline
\end{tabular}

Table 2: Herbs along with their dermatological action

Depilators: Beautifying was not only confined to skin and hair care. We can find references of formulations of depilation of unwanted hair from the body as well. Few of the examples are given below [18].

Lepa of Sudha (Calcium carbonate) and Haratala (Orpiment) along with hot water. 
Page 4 of 5

Lepa of Palasha kshara (Alkali of Butea monosperma), Kadali kanda kshara (Alkali of bark of Musa paradisiaca) and Haratala bhasma along with Kadali kanda swarasa.

Lepa of Haratala, Shankha bhasma (Calyx of conch shell) and Palasha kshara along with Kadali kanda swarasa.

\section{Abhyanga with Kusumbha taila in the opposite direction.}

These depilatories are designed by the combination of drugs possessing Rooksha (drying) and Kshara (Alkaline) property along with alkaline media. When such formulations are applied on the skin, they decrease the cellular energy level and thereby leading to decreased mitotic activity and cessation of hair follicle formation [20].

\section{Prevention of ageing and maintenance of a healthy skin and hair}

Rasayana chikitsa is one of the unique branches of Ayurveda which gives emphasis on Vayasthapana (Anti-ageing), Aayushkara (Prolongs life), Balakara (Increases strength), Medhakara (Nootropic effect), Jara vyadhi nashana (Overcomes geriatric disorders). The common Rasayanas given as prophylactic treatment for skin and hair are Narasimha rasayana, Agastya rasayana, Amruta bhallataka, Amrita prasha, Amalaki rasayana, Bhringarajadi rasayana.

The Vayasthapaka drugs like Triphala (Three fruits), Guduchi (Tinospora cordifolia), Nagabala (Sida veronicaefolia), Vidanga (Embelia ribes), Pippali (Piper longum) are proved to possess free radical scavenging activity. The potential use of these drugs as antioxidant has been validated to fight against age related problems by combating cellular damage induced by free-radicals like reactive oxygen and nitrogen species (ROS and RNS). Oxidative stress being one of the major causes for impairment of skin and hair [21]. Rasayanas can be adopted to prevent any damage and maintain youthfulness.

Lifestyle also has a major role in prolonging ageing and staying healthy. Ayurveda has provided guidelines to be followed every day and in every season in the form of Dinacharya and Rutucharya respectively. Habitual practice of Nasya, Taila gandoosha, Shiro Abhyanga, Pada abhyanga etc enhances the beauty of a person. According to Acharya Vagbhata, habitual application of Mukhalepa (Face pack) makes the vision keen; the face never loses lustre and always glows like a lotus flower. He has also mentioned different herbs to be used as face packs in different seasons. They are as follows [22].

Hemanta (Dewy season)-Kalamajja (Cotyledon of Ziziphus mauritiana), Vasamoola (Root of Adathoda vasica), Sabara (Symplocos racemosa), Goura sarshapa (Brassica alba).

Shishira (winter)-Simhimoola (Root of Solanum anguivi), Krishna (Piper longum), Tila (Sesamum indicum), Darvi twak (Bark of Coscinium fenestratum), Nistusha Yava (Dehusked hordeum vulgare).

Vasanta (spring)-Darbha moola (Root of Desmostachya bipinnata), Chandana (Santalum album), Usheera (Vetiveria zizanioides), Shireesha (Albizia lebbeck), Misi (Foeniculum vulgare), Tandula (Oryza sativa).

Grishma (summer)-Kumuda (Nymphaea nouchali), Utpala (Nymphaea stellata), Kalhara (Nymhoea alba), Doorva (Cynodon dactylon), Madhuka (Glycyrrhiza glabra), Chandana (Pterocarpus santalinus).
Varsha (Rainy)-Kaliyaka (Aquilaria agallocha), Tila (Sesamum indicum), Usheera (Vetiveria zizaniodes), Jatamamsi (Nardostachys jatamansi), Tagara (Valeriana wallichi), Padmaka (Prunus cerasoides)

Sharat (autumn)-Taleesapatra (Abies webbiana), Gundra (Saccharum arundinaceum), Pundrahva (Saccharum officinarum), Yashtimadhu (Glycyrrhiza glabra), Kasa (Saccharum spontaneum), Nata (Valeriana wallichi), Aguru (Aquilaria agallocha)

\section{Conclusion}

Health of skin and hair and youthfulness include proper moisture balance (Kapha in balance), effective functioning of the metabolic mechanisms that co-ordinate all the various chemical and hormonal reactions of the skin (Pitta in balance) and efficient circulation of blood and nutrients to different layers of the skin (Vata in balance). It also depends on the health of three Dhatus (Body tissues) viz. nutritional fluid (Rasa), Blood (Rakta) and muscle (Mamsa). Rasa supports all the Dhatus and keeps the skin healthy. Rakta, in association with liver function, helps detoxify the skin of toxins, while Mamsa provides firmness to the skin [23].

As the saying goes "Make your heart happy and your skin will glow", a swastha person who possesses pleasant Atma, sensory-motor organs and mind along with equilibrium of Dosha, Dhatu and Malakriya will have a beautiful body with glowing skin and lustrous, shiny hair.

\section{References}

1. Trivedi RP (1989) Astanga Sangraha with Sarvangasundari commentary. 15th edition. Baidyanath Ayurveda Bhavan Pvt Ltd, Nagapur.

2. Tripathi B (1997) Astanga Hridaya with Hindi Commentary (12th ed) Chaukhambha Sanskrit Sansthan, Varanasi.

3. Kumar P, Govindaraju U (2018) A bird's eye view on Kesha (Hair) in Charaka Samhita. J Ayurveda Integr Med Sci 3: 114-118

4. http:/shcs.ucdavis.edu/wellness/what-is-wellness

5. Joshi VMS, Joshi NH (1968) Maharashtra Rajya Sahitya Ani Samskruta Mandala, Mumbai.

6. Das B, Panda P, Meher SK, Bhuyan GC, Sahu DS, et al. (2015) Cosmetology in Ayurveda and its scope in Research. Res J Pharmacology \& P'dynamics 7: 40-45.

7. Murthy S (2008) Susruta Samhita by Acharya Sushruta. Chaukhamba Orientalia, Varanasi.

8. Sharma R K, Dash B (2007) Caraka Samhita by Agnivesa. Chowkhamba Sanskrit Series Office, Varanasi.

9. Tewari PV (2002) Kasyapa-Samhita or Vrddhajivakiya Tantra. Chaukhambha Visvabharati, Varanasi.

10. Kumar V (2017) A conceptual study on mode of action of Nasya. Int J Ayur Pharma Research 5: 100-102.

11. Prakash A, Debnath P, Arun Raj GR, Rao PN, Uppinakudru S (2013) A Review on the role of Jalaukavacharana (Hirudotherapy) in the management of venous ulcer. UJP 02: 38-43.

12. Madhukar LS, Nivrutti BA, Bhatngar V, Bhatngar S (2018) Physicoanatomical explanation of Abhyanga: An Ayurvedic massage technique for healthy life. J Tradit Med Clin Natur 7: 252.

13. Koyama T, Kobayashi K, Hama T, Murakami K, Ogawa R (2016) Standardized scalp massage results in increased hair thickness by inducing stretching forces to Dermal Papilla cells in the subcutaneous tissue. Eplasty 16: e8.

14. Murali Krishna C, Sivaram G, Malini S, Babu G (2018) Review of Ayurvedic herbs with Kesharanjana property in the management of Canities (Palitya). Int J Ayurvedic Medicine 9: 9-12.

15. Jha C B (2013) Sharangadhara samhita by Acharya Sharangadhara. Chaukhamba Surabharati Prakashan, Varanasi. 
16. Patil S, Choudhary AK (2015) Topical dosage forms (Lepa Kalpana) of Ayurveda: An unexplored treasure. International Journal of Green Pharmacy 9: S12-S18.

17. http://ayurvedaandpanchakarma.blogspot.com/2013/01/lepa.html

18. Mishra SN (2015) Bhaishajya Ratnavali by Kaviraj Govind Das Sen. Chaukhamba Surabharati Prakashan, Varanasi.

19. Sharma K, Joshi N, Goyal C (2015) Critical review of Ayurvedic Varnya herbs and their tyrosinase inhibition effect. Anc Sci Life 35: 18-25.

20. Gupta D, Mitti J, Patil M (2015) Pharmaceutico analytical study of Romashatana Lepa. Int J Ayur Pharma Research 3: 70-72.
21. Mukherjee S, Pawar N, Kulkarni O, Nagarkar B, Thopte S, et al. (2011) Evaluation of free-radical quenching properties of standard Ayurvedic formulation Vayasthapana Rasayana. BMC Complement Altern Med 11: 38.

22. Upadhyaya Y (2007) Ashtanga hrudayam by Acharya Vagbhata. Chaukhamba prakashan, Varanasi.

23. Datta HS, Paramesh R (2010) Trends in aging and skin care: Ayurvedic concepts. J Ayurveda Integr Med 1: 110-113. 